\title{
SODIUM SULPHOMETHYL DERIVATIVES OF POLYMYXINS
}

\author{
BY \\ MARGARET BARNETT, S. R. M. BUSHBY AND S. WILKINSON
}

From the Wellcome Research Laboratories, Beckenham, Kent

(Received April 6, 1964)

\begin{abstract}
Variations in the treatment of polymyxin B and polymyxin E (colistin) with formaldehyde and sodium bisulphite produce sulphomethyl derivatives which differ quantitatively in acute toxicity and in antibacterial activities in vitro and in vivo. The acute intravenous LD50 values of some sixty samples of these derivatives range from six- to more than eighty-fold those of the parent antibiotics; the in vitro antibacterial activities range from 2 to $12 \%$ and the in vivo activities from 20 to $50 \%$ of those of the parent antibiotics, with the most toxic derivatives showing the highest activities. When short and prolonged incubation methods are used, assays of the derivatives in solutions of different ages and of blood collected from man and dog after intramuscular injection, show that the antibacterial activities of these sulphomethyl derivatives depend on reversion to the unsubstituted form, and that the differences in the activities are due to variations in stability. These conclusions are supported by comparison of these sulphomethyl derivatives with stable acetyl derivatives. The lower in vivo activity is due, at least partly, to the high renal excretion of the substituted form. Electrophoresis shows that the derivatives are composite, the components corresponding to mono- to pentasulphomethyl polymyxin. Pain at the injection site is the most troublesome side-effect of polymyxin therapy, and this is avoided with these derivatives. In rats injected with quantities some twenty-times the usual human dose, the derivatives cause transitory decrease in urinary output and transitory proteinuria. After intramuscular injection of these derivatives into dogs, no antibiotic is detectable in the cerebrospinal fluid and concentrations present in the bile are not significantly different from those after injection of the parent antibiotic. When injected intracisternally into these animals, derivatives are less toxic than the parent compounds. These studies show that acute intravenous toxicity is a useful index of therapeutic efficiency and that derivatives with intravenous LD50 values of about $100 \mathrm{mg} / \mathrm{kg}$ are the most satisfactory ones. Because activity depends on reversion to the parent antibiotic, the use of these derivatives for topical application is contraindicated.
\end{abstract}

The reaction of a primary amine with an aldehyde and sodium sulphite, first described by Schiff (1866), converts basic substances to labile alkane sulphonic acids.

$$
\text { R.NH }{ }_{2}+\mathrm{R}^{1} \cdot \mathrm{CHO}+\mathrm{NaHSO}_{3} \longrightarrow \text { R.NH.CH. } \cdot \mathrm{SO}_{3} \mathrm{Na}
$$

This reaction was introduced into drug synthesis more than fifty years ago in a successful attempt to reduce the toxicity of phenetidin without loss of antipyretic activity (Lepetit, 1908). The reaction has since proved valuable with a wide range of drugs, which includes antibacterials, antipyretics, analgesics and central nervous stimulants, as a convenient means of modifying such properties as 
mode of action, toxicity, solubility and compatibility. The earlier work has been reviewed by Logemann \& Miori (1955), and Bersin (1957) has discussed the significance of transforming a cationic drug into an anionic one

in relation to its penetration and excretion.

$$
\text { R. } \stackrel{+}{\mathrm{N}_{3}} \longrightarrow \mathrm{R} . \mathrm{NH} . \mathrm{CH}_{2} \cdot \mathrm{SO}_{3}^{-}
$$

The reaction is equally applicable to basic polypeptides, and the treatment of polymyxins with formaldehyde and sodium bisulphite was reported by Stansly, Shepherd \& White (1947). These investigators claimed that this treatment produced a sulphomethyl derivative of polymyxin D which was not only less acutely toxic than the parent antibiotic but was also free from the defect of the unsubstituted antibiotic of producing painful irritation at subcutaneous or intramuscular injection sites. More recently the method has been used for overcoming the problem of the pain that develops at the injection sites of colistin (Koyama, 1957), another member of the polymyxin group of antibiotics now identified as polymyxin E (Suzaki, Hayashi, Fujikawa \& Tsukamoto, 1963 ; Wilkinson \& Lowe, 1964). This method of detoxication has also been applied to other basic antibiotics including gramicidin J (Tomoioka, Soga \& Umezuwa, 1960), neomycin, kanamycin and dihydrostreptomycin (Phillipe, Zuckerkandl \& Ores, 1959).

The purpose of this paper is to present experimental evidence to show that modifications in the method of treating polymyxins with formaldehyde and sodium bisulphite yield sulphomethyl derivatives which differ quantitatively in their pharmacological and chemotherapeutic activities, and that none of the derivatives so far produced is chemically homogeneous when examined electrophoretically. The pharmacological differences observed are variations in acute intravenous toxicity, and the chemotherapeutic studies show that reductions in antibacterial activity are proportional to decreases in toxicity.

Most of these studies have been made with polymyxin B, but some observations have also been made with polymyxin $\mathrm{E}$ (including preparations designated as colistin) because its sulphomethyl derivatives have been extensively used in man for the treatment of various bacterial infections; some studies with polymyxin $\mathrm{A}$ are also included.

\section{The antibiotics}

\section{METHODS}

The sulphomethyl derivatives were used as the sodium salts; those of polymyxin B were prepared from polymyxin B sulphate by introducing slight variations in the method of treatment with formaldehyde and sodium bisulphite, details of which will form the basis of a separate publication.

The sulphomethyl derivatives of polymyxin $\mathrm{E}$ were from two sources. One was prepared by us from polymyxin $\mathrm{E}$ sulphate and the other was a commercial brand of sodium sulphomethyl-colistin (Colomycin, Pharmax Ltd.). A sample of colistin sulphate was kindly supplied by Warner-Chilcott. To avoid confusion we have retained the name colistin, instead of using the proper name polymyxin $\mathrm{E}$, when specifically referring to this sample of polymyxin $\mathrm{E}$ or its derivatives.

We have regarded these preparations of the antibiotics as pure, and when referring to quantities and concentrations the increase in molecular weight of the derivatives due to the substitution has been ignored. With full substitution the molecular weight of polymyxin $B$ 
sulphate will increase from 1,447 to 1,782 and that of polymyxin $E$ sulphate from 1,413 to 1,748 ; the theoretical antibacterial potencies of the fully substituted derivatives are therefore 83 and $81 \%$, respectively, of those of the sulphates.

The polymyxin A sulphate was from a batch prepared in 1947.

\section{Acute intravenous toxicity}

This was determined in groups of six Swiss mice (weighing 18 to $20 \mathrm{~g}$ ) of the Schofield strain. Solutions of the antibiotics. were prepared in $0.85 \%$ saline and injected intravenously into the tail vein within $30 \mathrm{~min}$ of preparation; the volume injected was $0.025 \mathrm{ml} . / \mathrm{g}$. The dose ranges used were serial two-third dilutions, and the LD50 value and its $95 \%$ limits of error were calculated by the Thompson (1947) moving-average technique from the number of mice of each group dying within $24 \mathrm{hr}$.

\section{In vitro antibacterial activity}

18-hr incubation test. This standard test was done in both nutrient broth and nutrient agar. Freshly prepared serial two-third dilutions of the antibiotics in water were added to molten nutrient agar at $48^{\circ} \mathrm{C}$ and to nutrient broth, and each tube was inoculated with sufficient organisms of a sensitive strain to give approximately 100 colonies on the nutrient agar control slope. The minimum inhibitory concentration in nutrient agar was read as the lowest concentration that inhibited $90 \%$ or more of the growth in the control tubes, and that in nutrient broth as the lowest concentration that inhibited visible growth.

Short incubation test. Serial two-third dilutions of freshly prepared solutions, or solutions kept for specified periods, were made in $10 \mathrm{ml}$. volumes of nutrient broth and inoculated with $1 \mathrm{ml}$. of a 1:50 dilution of an $18 \mathrm{hr}$ nutrient broth culture of Escherichia coli. . After $3 \mathrm{hr}$ incubation at $37^{\circ} \mathrm{C}$ in a water bath, $1 \mathrm{ml}$. of $10 \%$ formol saline was added to each tube and the opacity was then read spectrophotometrically at $600 \mathrm{~m} \mu$. The absorbences of the antibiotic-containing tubes were expressed as percentages of that of a control tube containing no antibiotic, and the ED50 concentrations were read from probit-logarithmic graph paper.

Bactericidal test. Serial two-third dilutions of freshly prepared solutions of the antibiotics were made in $1 \mathrm{ml}$. volumes of oxalated dog blood, and immediately inoculated with $0.1 \mathrm{ml}$. of a $1: 20,00018 \mathrm{hr}$ broth culture of Klebsiella pneumoniae. After incubation in a water bath at $37^{\circ} \mathrm{C}$ for the specified period, $4.0 \mathrm{ml}$. of water was immediately added to each dilution and then $1 \mathrm{ml}$. of the mixture was placed in a petri dish, to which was added $15 \mathrm{ml}$. of nutrient agar. After $18 \mathrm{hr}$ incubation the colonies on each plate were counted and expressed as a percentage of those growing from antibiotic-free blood. The ED50 of the antibiotic was read from probit-logarithmic graph paper. The blood used in this test was collected from dogs (anaesthetized with pentobarbitone sodium) and kept frozen at $-70^{\circ} \mathrm{C}$ until required. Kleb. pneumoniae was chosen as the test organism because it was not affected hy the normal bactericidal action of dog blood; the size of the inoculum was such that approximately 500 colonies per plate would be grown from antibiotic-free blood. During an exposure of $1 \mathrm{hr}$ there was no significant multiplication of organisms in the control blood, but after $3 \mathrm{hr}$ the organisms multiplied freely. In some experiments the dilutions of the antibiotics were kept at $37^{\circ} \mathrm{C}$ for periods up to $3 \mathrm{hr}$ before being inoculated.

\section{In vivo antibacterial activity}

This was measured in Swiss mice of the Schofield strain using Esch. coli and Bordetella pertussis as test organisms.

In the Esch. coli experiments groups of ten mice were infected intraperitoneally with $4 \times 10^{\text {s }}$ organisms obtained from $18 \mathrm{hr}$ nutrient agar cultures suitably diluted in nutrient broth. The antibiotics were administered subcutaneously immediately after infection, $6 \mathrm{hr}$ later, and twice on the following day, solutions being freshly prepared at each time of dosing. The experiments were terminated at 7 days. 
In the experiments with Bord. pertussis, groups of ten mice were infected intracerebrally (during chloroform-ether anaesthesia) with $0.05 \mathrm{ml}$. of $1 \%$ casein hydrolysate containing 25,000 organisms from an $18 \mathrm{hr}$ culture on Bordet-Gengou medium. The antibiotics were administered subcutaneously immediately after infection, $6 \mathrm{hr}$ later, and twice on the following two days, solutions being freshly prepared at each time of administration. The experiments were terminated at 21 days. The ED50 doses of the antibiotics in both infections were calculated by the method of Litchfield \& Wilcoxon (1949).

\section{Concentrations of the antibiotics in blood and urine}

Concentrations were measured by the Bord. bronchiseptica diffusion method using polymyxin B sulphate in normal blood or urine as the standard. Urine samples were suitably diluted in normal urine and blood samples in normal blood to bring them on range. The use of polymyxin B sulphate as a standard results in a slight underestimation of the actual concentration of the antibiotic when it is in the substituted form.

\section{Bactericidal activity of the antibiotics in blood}

The bactericidal activity of the blood after intramuscular administration of the antibiotics was estimated by the method described for the bactericidal activity of the antibiotics. Blood taken before and at specified intervals after the injection of the antibiotics was placed in bottles containing potassium oxalate to give a concentration of $2 \mathrm{mg} / \mathrm{ml}$. and immediately frozen in a mixture of solid carbon dioxide and ethanol. The samples were kept at $-70^{\circ} \mathrm{C}$ until assayed, when they were thawed quickly and serially diluted in normal blood. Kleb. pneumoniae was used as the test organism for the estimations in the dog and Shigella sonnei for those in man. The exposure time was $1 \mathrm{hr}$. The ED50 dilution of the blood was calculated on probit-logarithmic graph paper from the percentage of organisms surviving in the dilutions of the blood compared with those present in the control, antibiotic-free blood.

\section{Antidiuresis and nephrotoxicity}

White rats of the Wistar strain, weighing approximately $100 \mathrm{~g}$, were used for these studies. In the first series of experiments the animals were given $10 \mathrm{ml}$. of water per $100 \mathrm{~g}$ of body weight by oral administration immediately before receiving the first dose of the antibiotic. The antibiotics were given twice daily by subcutaneous injection to groups of six or ten rats, fresh solutions being prepared for each injection. With the rats in metabolism cages the urine was collected for $7 \mathrm{hr}$ after the first dose, to measure the antidiuretic effect of the antibiotics. The animals were then transferred from the metabolism cages to feeding cages for $2 \mathrm{hr}$, after which they were replaced in the metabolism cages. At the end of the first $24 \mathrm{hr}$ the animals were allowed to feed for $1 \mathrm{hr}$, after which urine was collected for $7 \mathrm{hr}$; from then onwards till the end of the experiment the animals were allowed continuous access to food except for a $7 \mathrm{hr}$ period each day during which urine was collected; water was available throughout the experiment. The volumes of urine were measured and protein concentrations were determined by the biuret method. In the second series of experiments the rats were not given water before injection of the antibiotic.

At intervals some of the rats of each group and at the end of the experiment all the surviving rats of each group were killed and the kidneys were immediately fixed in buffered $10 \%$ formol saline, $p \mathbf{H} 7.0$. Sections were stained by Schiff's periodic acid reagent and Alcian Blue and examined histologically. The histological appearances were graded according to the following scheme:

0 : no detectable damage.

1: minimal damage to the brush borders of the subcapsular proximal portions of the proximal convoluted tubules.

2: definite damage to the brush borders and some cellular degeneration of the proximal portions of the proximal convoluted tubules. Early degeneration of some distal convoluted tubules. 
3: casts in proximal portions of the proximal convoluted tubules. Periodic acid Schiff positive granules in some cells of both portions of the proximal convoluted tubules. Definite cellular degeneration in some distal tubules.

4: as in group 3 but distal portions of the proximal convoluted tubules involved.

5: complete or nearly complete degeneration of proximal portions of the proximal and distal convoluted tubules. Considerable damage to distal portions of proximal convoluted tubules.

6: virtually complete degeneration of cortex.

The majority of the kidneys of untreated rats fell into grades 0 and 1 , but $20 \%$ of them were placed in grade 2 ; therefore in kidneys of treated animals only pathological changes of grades 3 to 6 were considered to be due to the effects of treatment with the antibiotic. In two control experiments, eleven groups of six untreated rats were submitted to the same procedures as the treated animals in order to determine the normal variations in urinary output and proteinuria under the conditions of the experiment.

\section{Electrophoretic analysis}

The electrophoretic patterns of the derivatives were compared by paper electrophoresis, using constant voltage and $0.05 \mathrm{M}$-acetate buffer, $p \mathrm{H}$ 5.7. The antibiotics $(10 \mu \mathrm{g})$ in the form of freshly prepared aqueous solutions were placed on $4 \mathrm{~cm}$. strips of Whatman No. 1 filter paper and, after the tank had been allowed to equilibrate for $30 \mathrm{~min}, 450 \mathrm{~V}$ was applied for $2 \mathrm{hr}$, after which the papers were dried for $30 \mathrm{~min}$ in the horizontal position at $55^{\circ} \mathrm{C}$. Four antibiotics were placed on each strip, each being separated by a narrow longitudinal $2 \mathrm{~mm}$ slit in the paper.

The position of the components of the antibiotics was determined by cutting a $5 \mathrm{~mm}$ strip from the paper and dividing it into $5 \mathrm{~mm}$ squares. To each square was added $0.002 \mathrm{ml}$. of glycine buffer $(0.35 \%)$ at $p \mathrm{H} 2.0$, and after $1 \mathrm{hr}$ each square was placed on a plate of nutrient agar seeded with Bord. bronchiseptica. The purpose of the glycine buffer was to convert the inactive components to the parent antibiotic. The sizes of zones of inhibition were compared with those surrounding similar pieces of filter paper containing known quantities of polymyxin B sulphate. The zones of inhibition, expressed as the equivalent activity of polymyxin B sulphate, were then plotted graphically to show the position and relative quantities of each active, or potentially active, component.

\section{Acute toxicity}

\section{RESULTS}

In mice the acute intravenous LD50 values of the sulphates of the parent antibiotics were not significantly different; the values observed with $95 \%$ limits of error were: polymyxin $\mathrm{B}, 8 \mathrm{mg} / \mathrm{kg}(7.0$ to $9.5 \mathrm{mg} / \mathrm{kg})$, polymyxin $\mathrm{E}, 9 \mathrm{mg} / \mathrm{kg}$ $(7.5$ to $11 \mathrm{mg} / \mathrm{kg})$, and colistin, $10 \mathrm{mg} / \mathrm{kg}(8.5$ to $11 \mathrm{mg} / \mathrm{kg})$. The intravenous LD50 values of some sixty samples of sulphomethyl derivatives ranged from 54 to $607 \mathrm{mg} / \mathrm{kg}$, the values forming a continuous sequence with no tendency to fall into groups.

With lethal doses of the parent antibiotics near the LD50 values, mice died from respiratory failure within about $1 \mathrm{~min}$. With near-lethal doses the animals passed through three stages before making a complete recovery within about $10 \mathrm{~min}$; the first stage consisted of vasoconstriction, muscular inco-ordination and respiratory distress, the second stage of intermittent clonic convulsions, and the third stage of flaccid paralysis associated with respiratory embarrassment and cyanosis. In contrast, with doses of the derivatives near the LD50 values both the toxic signs and 
their onset varied ; with the more toxic samples the onset of the signs did not differ greatly from that of those produced by the parent antibiotic but with the less toxic samples the first signs occurred in about $5 \mathrm{~min}$. The signs differed in that the first and second stages might be absent ; death was often delayed for $24 \mathrm{hr}$ or longer.

\section{In vitro antibacterial activity}

The antibacterial activity of the parent polymyxins is the result of rapid bactericidal action, but the minimum effective concentration depends on the number of organisms present; even with a defined number of bacteria its determination is complicated by a trailing "end-point."

The bacteriostatic tests commonly used for measuring minimum inhibitory concentrations give poor reproducibility with the polymyxins. In these tests a solid or fluid medium is used with an incubation period of $18 \mathrm{hr}$, and the activity is expressed in terms of the concentration that inhibits completely the growth of the inoculum (Bushby, 1955). The precision of the test can be improved by taking the end-point as that concentration which inhibits $90 \%$ or more of the inoculum. Table 1 shows the average activities found in three tests of polymyxin B, colistin,

TABLE 1

MINIMUM INHIBITORY CONCENTRATIONS ( $\mu \mathrm{G} / \mathrm{ML}$.) OF POLYMYXIN B SULPHATE, COLISTIN SULPHATE AND THEIR DERIVATIVES IN NUTRIENT BROTH AND NUTRJENT AGAR

Incubation was at $37^{\circ} \mathrm{C}$ for $18 \mathrm{hr}$. The intravenous acute toxicity to mice is shown for comparison. $\mathrm{SM}=$ sulphomethyl. LD50s are intravenous

\begin{tabular}{|c|c|c|c|c|c|}
\hline \multirow[b]{3}{*}{ Antibiotic } & \multirow[b]{3}{*}{$\underset{\text { (mg/kg) }}{\mathbf{L D} 50}$} & \multicolumn{4}{|c|}{ Minimum inhibitory concentration $(\mu \mathrm{g} / \mathrm{ml}$.) agains } \\
\hline & & \multicolumn{2}{|c|}{ Esch. coli } & \multicolumn{2}{|c|}{ Ps. aeruginosa } \\
\hline & & $\begin{array}{c}\text { Nutrient } \\
\text { broth }\end{array}$ & $\begin{array}{l}\text { Nutrient } \\
\text { agar }\end{array}$ & $\underset{\text { broth }}{\text { Nutrient }}$ & $\begin{array}{l}\text { Nutrient } \\
\text { agar }\end{array}$ \\
\hline $\begin{array}{l}\text { Polymyxin B sulphate } \\
\text { SM-Polymyxin B (P61/13/1b) } \\
\text { SM-Polymyxin B (P62/87) } \\
\text { SM-Polymyxin B (488/24A) } \\
\text { Colistin sulphate } \\
\text { SM-Colistin }\end{array}$ & $\begin{array}{r}8 \\
128 \\
135 \\
607 \\
10 \\
>550\end{array}$ & $\begin{array}{l}0 \cdot 24 \\
0 \cdot 46 \\
0 \cdot 39 \\
1 \cdot 19 \\
0 \cdot 29 \\
1 \cdot 31\end{array}$ & $\begin{array}{l}0 \cdot 21 \\
0 \cdot 38 \\
0 \cdot 43 \\
1 \cdot 50 \\
0 \cdot 27 \\
1 \cdot 31\end{array}$ & $\begin{array}{l}0.52 \\
0.69 \\
0.72 \\
1.18 \\
0.46 \\
1.97\end{array}$ & $\begin{array}{l}0.38 \\
1.03 \\
1.08 \\
1.88 \\
0 \cdot 52 \\
2 \cdot 34\end{array}$ \\
\hline
\end{tabular}

and four of their derivatives with acute intravenous LD50 values ranging from 128 to $607 \mathrm{mg} / \mathrm{kg}$. The test organisms were Esch. coli and Pseudomonas aeruginosa and the tests were done in both nutrient agar and nutrient broth.

The results show that the derivatives had one-half to one-sixth of the inhibitory activity of the parent antibiotic, the least toxic derivatives having the lowest activity.

In view of the labile nature of the amino substitutions, the activities of the derivatives shown by these methods may be overestimated because of breakdown to the parent antibiotics during the relatively long incubation period. This possibility was checked by increasing the number of organisms so that growth in nutrient broth in the absence of the antibiotics was visible after $3 \mathrm{hr}$ incubation. The results of a series of experiments are shown in Table 2, in which activities are expressed as percentages of that of polymyxin B sulphate. They show that the 
TABLE 2

\section{COMPARISON OF INTRAVENOUS TOXICITY FOR MICE AND IN VITRO ACTIVITY} AGAINST ESCH. COLI

The antibacterial activity was measured on solutions of the antibiotics in nutrient broth $p \mathbf{H ~ 7 . 6}$ after standing at $37^{\circ} \mathrm{C}$ for 0,3 and $24 \mathrm{hr}$ at a concentration of $10 \mu \mathrm{g} / \mathrm{ml}$. The activity was assayed by a four-fifth tube dilution method using a heavy inoculum. The $50 \%$ end-points were read spectrophotometrically after $3 \mathrm{hr}$ incubation. The activities are expressed as a percentage of the activity of polymyxin B sulphate and are given as the mean results of four or more tests with the standard deviations in brackets. SM = sulphomethyl. LD50s are intravenous, and $95 \%$ limits of error are in parentheses

\section{Antibiotic}

Polymyxin B sulphate

Polymyxin E sulphate

Colistin sulphate

SM-Polymyxin B (P61/13/3)

SM-Polymyxin B (P62/87)

SM-Polymyxin B (AN 5747)

SM-Polymyxin B (488/24A)

SM-Colistin

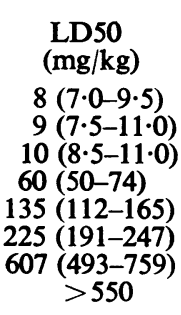

Antibacterial activity after

\begin{tabular}{ccc}
\hline $0 \mathrm{hr}$ & $3 \mathrm{hr}$ & $24 \mathrm{hr}$ \\
100 & 100 & 100 \\
$97(9 \cdot 0)$ & - & - \\
$108(10 \cdot 7)$ & $\overline{-}$ & $\overline{-}$ \\
$37(4 \cdot 7)$ & $44(12 \cdot 5)$ & $78 \cdot 4)$ \\
$24(6 \cdot 3)$ & $34(9 \cdot 3)$ & $74(9 \cdot 2)$ \\
$10(1 \cdot 9)$ & $19(4 \cdot 3)$ & $68(11 \cdot 0)$ \\
$6(1 \cdot 3)$ & $14(3 \cdot 2)$ & $69(10 \cdot 2)$ \\
$5(1 \cdot 0)$ & $12(4 \cdot 0)$ & $70(8 \cdot 8)$
\end{tabular}

least toxic of the derivatives, namely the 488/24A sample of sulphomethylpolymyxin B and the sample of sulphomethyl-colistin, under these conditions have only about one-twentieth of the activity of the parent antibiotics. The activity is therefore only about one-fourth of that revealed in the prolonged incubation tests. However, the activities shown by the two tests became closer when the antibiotics were kept in solution at a concentration of $10 \mu \mathrm{g} / \mathrm{ml}$. at $37^{\circ} \mathrm{C}$ for $3 \mathrm{hr}$ before being assayed and after $24 \mathrm{hr}$ the activity was almost equivalent to that of the parent antibiotic, that is 81 to $83 \%$, allowing for differences in molecular weight.

Additional evidence of the loss of activity that occurs with the conversion of these antibiotics to their respective derivatives was obtained by measuring their bactericidal activities against Kleb. pneumoniae in whole blood. Table 3 gives the results of a typical experiment. It shows that the concentrations of the less active derivatives needed to kill $50 \%$ of the organisms in $30 \mathrm{~min}$ are about sixty-times greater than that of polymyxin B sulphate; but if the antibiotic is allowed to act on the organisms for $3 \mathrm{hr}$ the quantity needed for this effect is reduced to about twenty-times that of the parent. The more toxic derivatives, P62/87 and P62/113, are almost ten-times as active as these less toxic ones.

TABLE 3

INCREASE IN THE BACTERICIDAL ACTIVITY OF THE DERIVATIVES OF THE POLYMYXINS AGAINST KLEB. PNEUMONIAE

Incubation was at $37^{\circ} \mathrm{C}$ for $3 \mathrm{hr}$. The numbers of viable bacilli present in decreasing concentrations of the antibiotics were determined after $0.5,1.0$ and $3.0 \mathrm{hr}$, and the concentrations that killed $50 \%$ of the inoculum were calculated. $\mathrm{SM}=$ sulphomethyl. LD50s are intravenous

Antibiotic

Polymyxin B sulphate

SM-Polymyxn B (P62/87)

SM-Polymyxin B (488/24A)

SM-Polymyxin E (P62/113)

SM-Colistin
LD50

(mg/kg)

8
135
607
150
$>550$

$\operatorname{ED50}(\mu \mathrm{g} / \mathrm{ml}$.$) after$

\begin{tabular}{cll}
\hline $0.5 \mathrm{hr}$ & $1 \mathrm{hr}$ & $3 \mathrm{hr}$ \\
0.27 & 0.17 & 0.14 \\
2.15 & 0.9 & 0.7 \\
14.0 & 7.6 & 2.8 \\
1.05 & 0.5 & 0.32 \\
19.7 & 5.6 & 2.2
\end{tabular}


In a second experiment the antibiotics in concentrations of $50 \mu \mathrm{g} / \mathrm{ml}$. in blood were incubated at $37^{\circ} \mathrm{C}$ for $1 \mathrm{hr}$ and $3 \mathrm{hr}$ before their bactericidal activities were measured. The results (Table 4) confirmed that the activities of the derivatives increase during incubation. This second experiment therefore indicates that the increase in activity noted in the first experiment when the time of contact between bacteria and derivative was increased from 1 to $3 \mathrm{hr}$ was not entirely, if at all, due to a slower intrinsic bactericidal action of the derivatives.

TABLE 4

BACTERICIDAL ACTIVITY OF BLOOD CONTAINING $50 \mu \mathrm{G} / \mathrm{ML}$. OF ANTIBIOTIC AFTER INCUBATION

Incubation was at $37^{\circ} \mathrm{C}$ for 0,1 and $3 \mathrm{hr}$. At the end of these intervals two-third dilutions of the blood were infected with Kleb. pneumoniae. The concentration that killed $50 \%$ of the inoculum after $1 \mathrm{hr}$ further incubation was then determined by viable counts. SM=sulphomethyl. LD50s are intravenous

\begin{tabular}{ccccc} 
& & \multicolumn{3}{c}{ ED50 $(\mu \mathrm{g} / \mathrm{ml}$.$) after$} \\
\cline { 2 - 5 } Antibiotic & $\begin{array}{c}\text { LD50 } \\
(\mathbf{m g} / \mathbf{k g})\end{array}$ & $\mathbf{0 ~ h r}$ & $1 \mathrm{hr}$ & $3 \mathrm{hr}$ \\
Polymyxin B sulphate & 8 & $0 \cdot 18$ & $0 \cdot 12$ & $0 \cdot 10$ \\
SM-Polymyxin B (P62/87) & 135 & 0.94 & 0.6 & 0.32 \\
SM-Polymyxin B (488/24A) & 607 & $4 \cdot 7$ & 1.35 & 0.48 \\
SM-Polymyxin E (P62/113) & 150 & $0 \cdot 48$ & 0.35 & $0 \cdot 18$ \\
SM-Colistin & $>550$ & $7 \cdot 0$ & $1 \cdot 2$ & 0.44
\end{tabular}

In vivo antibacterial activity

The effects of the formaldehyde-bisulphite treatment on the in vivo activity of the antibiotics were studied in two experimental infections of mice. Esch. coli and Bord. pertussis were chosen as the test organisms because of the difference in the acuteness of the illness that they produce in mice; untreated mice infected with Esch. coli die within $24 \mathrm{hr}$ whilst those infected with Bord. pertussis die in 5 to 8 days. Because the ED50 value varies from experiment to experiment, polymyxin B sulphate was included in each experiment and the activities of the various derivatives

TABLE 5

COMPARISON OF INTRAVENOUS LD50 AND IN VIVO ACTIVITY IN MICE INFECTED WITH ESCH. COLI AND BORD. PERTUSSIS

The in vivo activity is expressed as a percentage of that of polymyxin B sulphate. SM=sulphomethyl. LD50s are intravenous, with $95 \%$ limits of error in parentheses

\begin{tabular}{|c|c|c|c|c|c|c|c|}
\hline \multirow[b]{3}{*}{ Antibiotic } & \multirow[b]{3}{*}{$\begin{array}{l}\text { LD50 } \\
(\mathrm{mg} / \mathrm{kg})\end{array}$} & \multicolumn{6}{|c|}{ In vivo activity against } \\
\hline & & \multicolumn{3}{|c|}{ Esch. coli } & \multicolumn{3}{|c|}{ Bord. pertussis } \\
\hline & & $\begin{array}{c}\text { Activ- } \\
\text { ity }\end{array}$ & $\begin{array}{c}95 \% \\
\text { limits of } \\
\text { error }\end{array}$ & $\begin{array}{c}\text { No. } \\
\text { of } \\
\text { expts. }\end{array}$ & $\begin{array}{l}\text { Activ- } \\
\text { ity }\end{array}$ & $\begin{array}{c}95 \% \\
\text { limits of } \\
\text { error }\end{array}$ & $\begin{array}{c}\text { No. } \\
\text { of } \\
\text { expts. }\end{array}$ \\
\hline $\begin{array}{l}\text { Polymyxin B sulphate } \\
\text { SM-Polymyxin B (P61/13/1) } \\
\text { SM-Polymyxin B (P62/87) } \\
\text { SM-Polymyxin B (AN 5747) } \\
\text { SM-Polymyxin B (27-482-02) } \\
\text { SM-Polymyxin B (488/24A) } \\
\text { Polymyxin E sulphate } \\
\text { SM-Polymyxin E (P62/112) } \\
\text { Colistin sulphate } \\
\text { SM-Colistin }\end{array}$ & $\begin{array}{c}8 \cdot 0(7 \cdot 0-9 \cdot 5) \\
54(47-64) \\
135(112-165) \\
225(191-247) \\
259(214-304) \\
607(493-759) \\
9 \cdot 0(7 \cdot 5-11 \cdot 0) \\
157(135-187) \\
10 \cdot 0(8 \cdot 5-11 \cdot 0) \\
>550\end{array}$ & $\begin{array}{r}100 \\
45 \\
23 \\
21 \\
11 \\
8 \\
120 \\
23 \\
87 \\
3 \cdot 4\end{array}$ & $\begin{array}{l}-\overline{29-70} \\
18-29 \\
13-33 \\
7-16 \\
6-10 \\
91-159 \\
15-34 \\
65-116 \\
2 \cdot 8-4 \cdot 1\end{array}$ & $\begin{array}{r}13 \\
4 \\
6 \\
1 \\
2 \\
9 \\
4 \\
2 \\
4 \\
10\end{array}$ & $\begin{array}{r}100 \\
48 \\
34 \\
19 \\
12 \\
86 \\
34 \\
72 \\
10\end{array}$ & $\begin{array}{l}21-110 \\
16-73 \\
-\overline{7-56} \\
7-22 \\
48-157 \\
14-85 \\
39-132 \\
7-15\end{array}$ & $\begin{array}{r}6 \\
3 \\
4 \\
\\
2 \\
6 \\
4 \\
2 \\
4 \\
12\end{array}$ \\
\hline
\end{tabular}




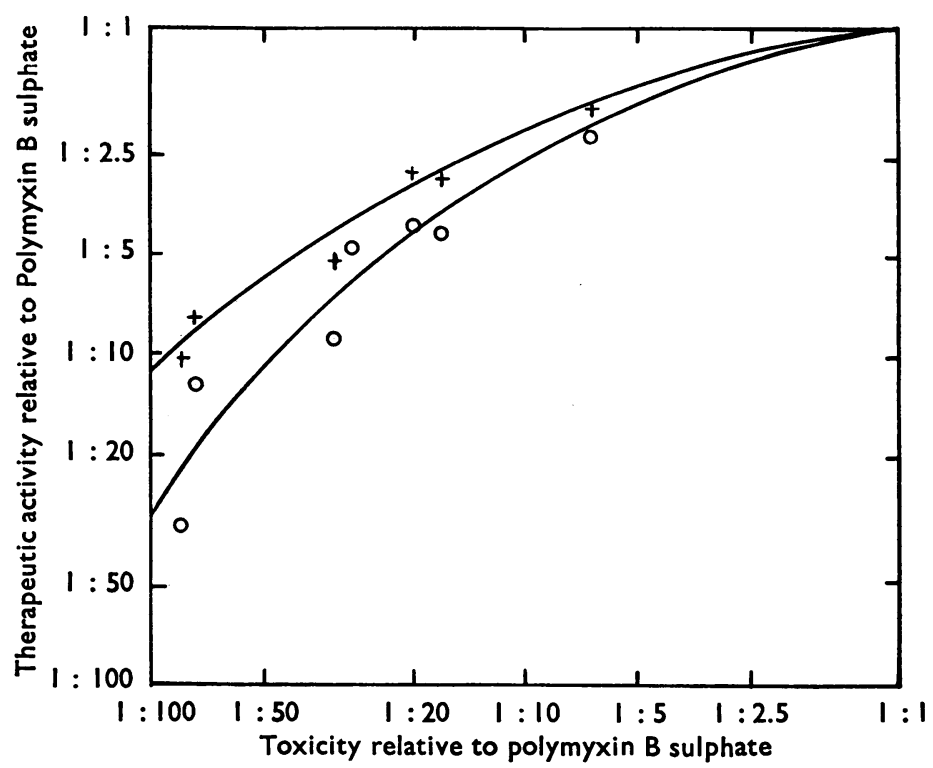

Fig. 1. Relationship between LD50 and in vivo activity of the sulphomethyl derivatives. The therapeutic activity was measured in mice infected with Esch. coli (acute infection, circles) and Bord. pertussis (chronic infection, crosses) and the acute intravenous toxicities and therapeutic activities are expressed as ratios of those of polymyxin. B sulphate.

were expressed as percentages of that of polymyxin B sulphate. The antibiotics were usually tested in more than one experiment and the mean activities together with the intravenous LD50 values of the respective antibiotics are shown in Table 5.

The results show that all the derivatives have activities which are less than $50 \%$ of that of polymyxin B sulphate and that the least active derivatives are those with the lowest toxicities (Fig. 1); with these latter derivatives the activity is only about one-tenth of that polymyxin B sulphate in the more chronic infection with Bord. pertussis and even less in the acute Esch. coli infection.

\section{Antidiuresis}

The effects of single doses of these antibiotics on excretion of urine of groups of rats that had been hydrated are shown in Table 6 . In this table the volumes of urine excreted by the treated groups during a $7 \mathrm{hr}$ period after the injection of the antibiotics are expressed as ratios of the volume excreted by the control untreated group, this volume being expressed as 1.0. When two experiments were performed the results are given as the arithmetic mean. In the control experiments referred to in Methods, and in which eleven groups of untreated rats were submitted to the same procedures as the treated animals, the quantity of urine excreted during the first $7 \mathrm{hr}$ varied greatly; the average volumes per group were 54 and $42.5 \mathrm{ml}$., respectively, in the two experiments but the coefficient of variation was $32 \%$ in each. Therefore, in assessing the effects of treatment only ratios greater than 1.64 and less than 0.36 . that is twice the coefficient of variation, are probably significant. 
TABLE 6

ANTIDIURETIC EFFECTS AND NEPHROTOXICITY IN RATS FOLLOWING TREATMENT WITH POLYMYXIN B SULPHATE, COLISTIN SULPHATE AND THEIR DERIVATIVES

The antibiotics were administered subcutaneously twice daily on two consecutive days. The rats were hydrated before the first dose and the kidneys were removed on the 5th day. Polymyxin A was included as a standard nephrotoxic antibiotic. The volumes of urine, the concentrations and quantities of protein excreted are expressed as ratios of those excreted by untreated rats. $\mathbf{S M}=$ sulphomethyl. LD50s are intravenous

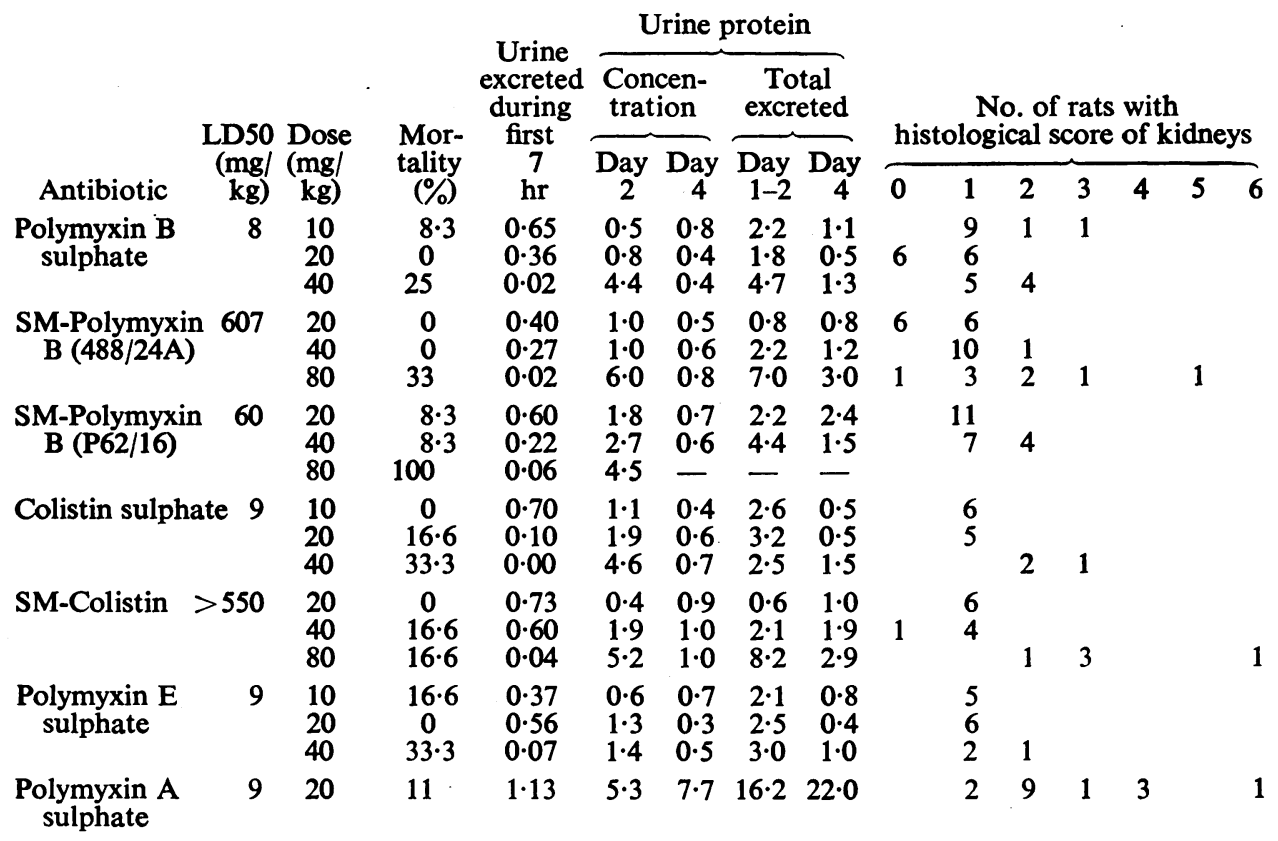

In spite of the large normal variation, the results show that polymyxins $B$ and $E$ (and colistin) in their unsubstituted forms produce graded responses over the dose range of 10 to $40 \mathrm{mg} / \mathrm{kg}$, the maximum doses, which were lethal for some of the rats, causing almost complete anuria. The substituted forms of polymyxin B and colistin examined in these experiments had intravenous LD50 values ranging from 60 to $607 \mathrm{mg} / \mathrm{kg}$, and when given in large doses they all produced a decrease in the volume of urine excreted; the doses had to be increased to $80 \mathrm{mg} / \mathrm{kg}$ to produce anuria. Although the volumes excreted on the days 2 to 4 are not shown, they did not differ from those of untreated rats.

\section{Nephrotoxicity}

The rats used in these experiments normally excreted a variable quantity of protein ; and the coefficient of variation in the eleven groups of rats of the control experiments, irrespective of whether the protein was expressed as concentration or total protein excreted, was approximately $40 \%$. In order to facilitate comparisons between the effects of the different antibiotics on proteinuria, the concentrations and total quantities of protein excreted during and after treatment were calculated as ratios of the protein excreted by untreated rats. The proteinuria of untreated 
rats was expressed as 1.0 but, because of the day-to-day variations in normal excretion, concentration ratios and total protein ratios of less than 2.0 , approximately twice the coefficient of variation, probably do not indicate a significant change in proteinuria.

The results of an experiment in which six rats were treated twice daily for 2 days showed that high doses of the parent antibiotics caused an increase in proteinuria. Urine was collected during the hours 0 to 24 and 41 to 48 of the treatment period, and the concentration of protein in the second sample (day 2) and the total amount of protein in both samples (days 1-2) of each treatment group are shown in Table 6 ; the Table also shows the concentration and quantity of protein present in the urine collected during $7 \mathrm{hr}$ of the second day after the cessation of treatment (day 4). Polymyxin A was included in these experiments because of its known nephrotoxicity for man, and in doses of $20 \mathrm{mg} / \mathrm{kg}$ it produced a sixteen-fold increase in the protein excreted during the second day of treatment, and two days later, in spite of the cessation of treatment, the increase had risen to twenty-two-fold. In contrast to these effects, similar doses of polymyxin B sulphate, polymyxin E sulphate and colistin sulphate produced no significant rise in protein, and doubling the dose to $40 \mathrm{mg} / \mathrm{kg}$, which was lethal for some of the rats, produced only transient proteinuria. The deaths that occurred from these high doses usually occurred during the first day of treatment.

Histological examination of the kidneys of animals killed 2 days after the end of treatment confirmed that gross damage to the kidneys occurred only with very high doses of the unsubstituted antibiotics. These findings are summarized in Table 6, where they are expressed in terms of the score described earlier (see Methods). Pathological changes allotted score 2 were seen in the kidneys of about $20 \%$ of the untreated animals but as they occurred more frequently in treated animals they probably signify mild nephrotoxicity. The changes represented by scores 3 and 4 were not observed in untreated rats and so should be regarded as evidence of nephrotoxicity; as they were not seen in rats killed 2 days after the cessation of treatment the damage is probably reversible.

Judged by proteinuria and histological changes, the sulphomethyl derivatives of polymyxin B and colistin were less nephrotoxic than the parent antibiotics; no damage was seen with the $40 \mathrm{mg} / \mathrm{kg}$ doses although definite damage was produced by $80 \mathrm{mg} / \mathrm{kg}$. There appears to be little difference in nephrotoxicity between the derivative of polymyxin B of low intravenous toxicity $(488 / 24 \mathrm{~A})$ and the more toxic derivative (P62/16).

In a second experiment, in which the treatment was continued for 5 days, the damage produced by 2 days' treatment was not intensified by further treatment, and the histological changes present in the kidneys of animals killed 3 days after the end of treatment with polymyxin B, polymyxin $\mathrm{E}$ and colistin were minimal.

\section{Concentrations of antibiotic in body fluids}

Blood. Polymyxins can be detected in body fluids only by biological methods, and for measuring concentrations we have used the diffusion method with Bord. 
bronchiseptica as the test organism. Due to the increase in antibacterial activity that occurs during the incubation of dilute solutions of the derivatives, however, the method gives no indication of the form in which the derivative is present in the body, that is the method does not measure the actual antibacterial activity of the fluids. We have therefore endeavoured to measure the bactericidal activity of the blood by determining the dilution of the blood that kills $50 \%$ of an inoculum of a sensitive organism that is not susceptible to the natural bactericidal activity of blood during $1 \mathrm{hr}$ incubation at $37^{\circ} \mathrm{C}$.

The blood concentration and the bactericidal titre of the blood of five dogs given intramuscularly, on four separate occasions, equimolar doses of polymyxin B sulphate, two derivatives of polymyxin B and one each of polymyxin $E$ and colistin, are given in Table 7. The dose of polymyxin B sulphate was $3.75 \mathrm{mg} / \mathrm{kg}$, and Kleb. pneumoniae was used as the test organism in the bactericidal determinations.

The results show that although polymyxin B sulphate, at $1 \mathrm{hr}$ after the injection, produced a concentration of antibiotic in the blood approximately one-third of those obtained with the derivatives, the bactericidal titres were on average about seven-times higher than those of the two low toxicity derivatives, 488/24A and the sample of sulphomethyl-colistin. The bactericidal titres of the blood produced by the two relatively more toxic derivatives, $\mathrm{P} 62 / 87$ and $\mathrm{P} 62 / 113$, are several times higher than those produced by the low toxicity derivatives, in spite of the concentrations being similar. These differences were still apparent but less marked in the blood taken $3 \mathrm{hr}$ after the injection.

Similar observations were also made in man. In a cross-over experiment, eight normal adult males were each given equimolar doses of polymyxin B sulphate and three sulphomethyl derivatives. Two of the derivatives had relatively high intravenous toxicities and the third was of low toxicity ; these derivatives were sulphomethyl-polymyxin B (intravenous LD50, $100 \mathrm{mg} / \mathrm{kg}$ ), sulphomethyl-polymyxin E (intravenous LD50 $150 \mathrm{mg} / \mathrm{kg}$ ) and sulphomethyl-colistin (intravenous LD50> $550 \mathrm{mg} / \mathrm{kg}$ ). The dose of polymyxin B sulphate was $60 \mathrm{mg}$. The results are shown in Table 8, and the relationship between the antibacterial activities expressed as the concentration of the antibiotic, measured by the Bord. bronchiseptica diffusion test, and as the bactericidal titre against Shig. sonnei are shown in Fig. 2. The results are similar to those obtained with the dog, except that the concentrations of the low toxicity derivative are less than those of polymyxin B sulphate. The bactericidal titres of blood taken $1 \mathrm{hr}$ after the injection of this low toxicity derivative are about one-sixth of those obtained with the more acutely toxic derivatives and about one-twelfth of those obtained with polymyxin B sulphate; in blood taken at $3 \mathrm{hr}$, however, the activity has on average increased three-fold.

These differences in bactericidal titre and concentration indicate that the derivatives circulate in the blood partly in the substituted form, and this explanation is supported by the observation that the bactericidal titre of blood taken from two dogs $1 \mathrm{hr}$ after the injection of $4.7 \mathrm{mg} / \mathrm{kg}$ of sulphomethyl-colistin (intravenous LD50>550 mg/kg) increased from approximately $1: 3$ to $1: 10$ when kept at $37^{\circ} \mathrm{C}$ for $3 \mathrm{hr}$. 
564 MARGARET BARNETT, S. R. M. BUSHBY and S. WILKINSON

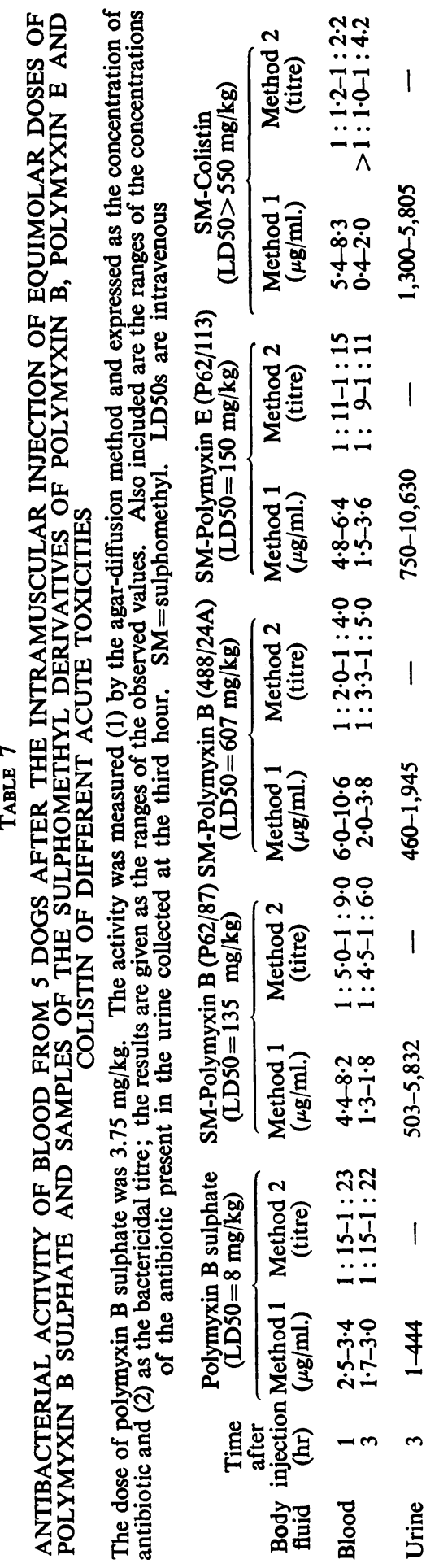


TABLE 8

ANTIBACTERIAL ACTIVITY OF BLOOD FROM ADULT HUMAN VOLUNTEERS AFTER THE INTRAMUSCULAR INJECTION OF EQUIMOLAR DOSES OF POLYMYXIN B SULPHATE AND SAMPLES OF THE SULPHOMETHYL DERIVATIVES OF POLYMYXIN B, POLYMYXIN E AND COLISTIN OF DIFFERENT ACUTE TOXICITIES

The dose of polymyxin B sulphate was $60 \mathrm{mg}$. The activity was measured (1) by the agar-diffusion method and expressed as the concentration of antibiotic and (2) as the bactericidal titre. The values expressed are geometric means of eight individuals. For both estimates of concentration and of bactericidal titre the $P 95$ limits of the means were of the order of $\pm 7 \%$. SM $=$ sulphomethyl. LD50s are intravenous

\begin{tabular}{|c|c|c|c|c|c|c|c|c|}
\hline \multirow{2}{*}{$\begin{array}{c}\text { Time } \\
\text { after } \\
\text { injection } \\
\text { (hr) }\end{array}$} & \multicolumn{2}{|c|}{$\begin{array}{l}\text { Polymyxin B sulphate } \\
\text { (LD50 }=8 \mathrm{mg} / \mathrm{kg} \text { ) }\end{array}$} & \multicolumn{2}{|c|}{$\begin{array}{c}\begin{array}{c}\text { SM-Polymyxin B } \\
(\mathrm{LD} 50=100 \mathrm{mg} / \mathrm{kg})\end{array}\end{array}$} & \multicolumn{2}{|c|}{$\begin{array}{c}\begin{array}{c}\text { SM-Polymyxin E } \\
(\mathrm{LD} 50=150 \mathrm{mg} / \mathrm{kg})\end{array} \\
.\end{array}$} & \multicolumn{2}{|c|}{$\begin{array}{c}\begin{array}{c}\text { SM-Colistin } \\
(\mathrm{LD} 50>550 \mathrm{mg} / \mathrm{kg})\end{array} \\
\end{array}$} \\
\hline & $\begin{array}{l}\text { Method } 1 \\
(\mu \mathrm{g} / \mathrm{ml} .)\end{array}$ & $\begin{array}{l}\text { Method } 2 \\
\text { (titre) }\end{array}$ & $\begin{array}{l}\text { Method } 1 \\
(\mu \mathrm{g} / \mathrm{ml} .)\end{array}$ & $\underset{\text { (titre) }}{\text { Method } 2}$ & $\begin{array}{l}\text { Method } 1 \\
(\mu \mathrm{g} / \mathrm{ml} .)\end{array}$ & $\underset{\text { (titre) }}{\text { Method } 2}$ & $\begin{array}{l}\text { Method } 1 \\
(\mu \mathrm{g} / \mathrm{ml} .)\end{array}$ & $\begin{array}{l}\text { Method } 2 \\
\text { (titre) }\end{array}$ \\
\hline $\begin{array}{l}0.5 \\
1.0 \\
2.0 \\
3.0 \\
4 \cdot 0 \\
6.0\end{array}$ & $\begin{array}{l}1.31 \\
1.46 \\
1.27 \\
1.06 \\
0.98 \\
0.64\end{array}$ & $\begin{array}{c}1: \overline{23} \cdot 4 \\
1: \overline{19 \cdot 2} \\
=\end{array}$ & $\begin{array}{l}0.98 \\
1.89 \\
1.98 \\
1.51 \\
1.10 \\
0.59\end{array}$ & $\begin{array}{c}1: \overline{9} \cdot 7 \\
1: \overline{13 \cdot 4} \\
=\end{array}$ & $\begin{array}{l}0.78 \\
1.58 \\
1.41 \\
0.92 \\
0.74 \\
0.34\end{array}$ & $\begin{array}{c}1: \overline{12 \cdot 4} \\
1: \overline{17 \cdot 4} \\
=\end{array}$ & $\begin{array}{l}0.39 \\
0.89 \\
0.86 \\
0.69 \\
0.48 \\
0.21\end{array}$ & $\begin{array}{c}1: \overline{2} \cdot 1 \\
1: \overline{5} \cdot 7 \\
=\end{array}$ \\
\hline
\end{tabular}

Urine. Samples of urine were collected at the third hour from the dogs and at the first, third and sixth hours from the men of the above experiment, and the concentrations of antibiotic were assayed by the Bord. bronchiseptica diffusion method using the parent antibiotic as the standard. The results for dog and man are given in Tables 7 and 9, respectively, and, as the volumes of urine passed by

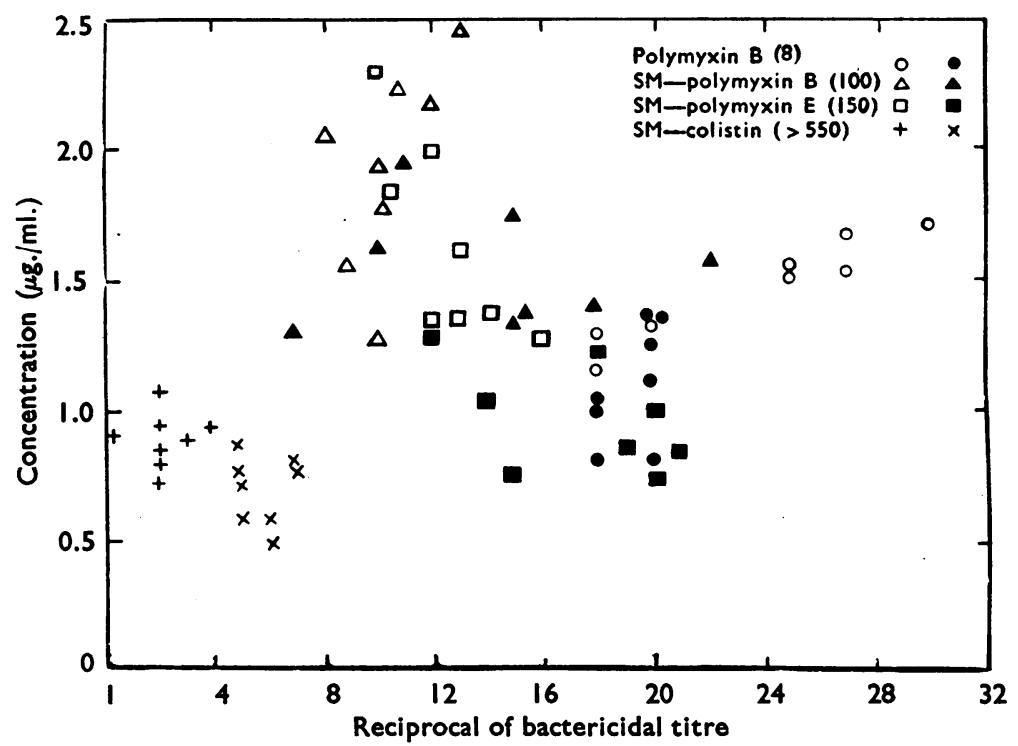

Fig. 2. Relationship between the concentrations of polymyxin in human blood expressed as: (1) $\mu \mathrm{g} / \mathrm{ml}$., measured by the agar diffusion method, and (2) the bactericidal titre of the blood against Shig. sonnei. The measurements were made on blood taken $1 \mathrm{hr}$ (empty symbols) and $3 \mathrm{hr}$ (filled symbols) after the intramuscular injection of equimolar doses of polymyxin $B$ sulphate, sulphomethyl-polymyxin B, sulphomethyl-polymyxin E and sulphomethyl-colistin of different acute toxicities. The dose of polymyxin B sulphate was $60 \mathrm{mg}$. Intravenous LD50 values $(\mathrm{mg} / \mathrm{kg})$ are in parentheses. 
TABLE 9

ANTIBIOTIC PRESENT IN URINE FROM ADULT HUMAN VOLUNTEERS AFTER THE INTRAMUSCULAR INJECTION OF EQUIMOLAR DOSES OF POLYMYXIN B SULPHATE AND SAMPLES OF THE SULPHOMETHYL DERIVATIVES OF POLYMYXIN B, POLYMYXIN E AND COLISTIN OF DIFFERENT ACUTE TOXICITIES

The dose of polymyxin B sulphate was $60 \mathrm{mg}$. The antibiotic is expressed (1) as the concentration in $\mu \mathrm{g} / \mathrm{ml}$., and (2) as a percentage of the dose injected. Values are geometric means of eight individuals. Variation among the polymyxin B sulphate results was significantly greater than among those for the derivatives. $P 95$ limits for the means with polymyxin B sulphate were approximately 68 to $147 \%$ of the stated values. For the derivatives the $P 95$ limits of means were of the order of 86 to $117 \%$. SM=sulphomethyl. LD50s are intravenous

\begin{tabular}{|c|c|c|c|c|c|c|c|c|}
\hline \multirow{3}{*}{$\begin{array}{c}\text { Time } \\
\text { after } \\
\text { injection } \\
\text { (hr) }\end{array}$} & \multicolumn{2}{|c|}{$\begin{array}{l}\text { Polymyxin B sulphate } \\
\text { (LD50=8 mg/kg) }\end{array}$} & \multicolumn{2}{|c|}{$\begin{array}{l}\text { SM-Polymyxin B } \\
(\mathrm{LD} 50=100 \mathrm{mg} / \mathrm{kg})\end{array}$} & \multicolumn{2}{|c|}{$\begin{array}{l}\text { SM-Polymyxin E } \\
(\mathrm{LD} 50=150 \mathrm{mg} / \mathrm{kg})\end{array}$} & \multicolumn{2}{|c|}{$\begin{array}{c}\text { SM-Colistin } \\
(\text { LD50 }>550 \mathrm{mg} / \mathrm{kg})\end{array}$} \\
\hline & Conce & ntration & Conce & ntration & Conce & ntration & Conce & entration \\
\hline & $(\mu \mathrm{g} / \mathrm{ml})$. & $\%$ of dose & $(\mu \mathrm{g} / \mathrm{ml})$. & $\%$ of dose & $(\mu \mathrm{g} / \mathrm{ml})$. & $\%$ of dose & $(\mu \mathrm{g} / \mathrm{ml})$. & $\%$ of dose \\
\hline $\begin{array}{l}0-1 \\
1-3 \\
3-6 \\
0-6\end{array}$ & $\begin{array}{l}0.57 \\
1.63 \\
0.44 \\
-\end{array}$ & $\begin{array}{l}0.04 \\
0 \cdot 22 \\
0 \cdot 10 \\
0 \cdot 36\end{array}$ & $\begin{array}{l}34 \\
90 \\
24 \\
-\end{array}$ & $\begin{array}{r}3 \cdot 2 \\
13 \cdot 2 \\
5 \cdot 8 \\
22 \cdot 2\end{array}$ & $\begin{array}{r}126 \\
198 \\
38 \\
\end{array}$ & $\begin{array}{r}11 \cdot 2 \\
27 \cdot 7 \\
7 \cdot 8 \\
46 \cdot 7\end{array}$ & $\begin{array}{r}136 \\
179 \\
64 \\
\end{array}$ & $\begin{array}{l}12 \cdot 9 \\
26 \cdot 3 \\
16 \cdot 7 \\
55 \cdot 9\end{array}$ \\
\hline
\end{tabular}

the men were recorded, the mean percentage of the dose of the antibiotic excreted during each of the respective periods is also shown.

After the injection of the parent antibiotic very little of the antibiotic was excreted in the urine ; during the $6 \mathrm{hr}$ period after the injection the percentages of the injected dose excreted by man ranged from 0.25 to $2.2 \%$. In contrast, after injection of the sulphomethyl derivatives high concentrations of the antibiotic were present in the urine ; the percentages excreted by man ranged from 16.6 to $100 \%$ and they were highest with the less acutely toxic derivatives.

Electrophoretograms, in which Bord. bronchiseptica was used for detecting the components, were made on samples of urine which were passed at 1 and $4 \mathrm{hr}$ after the injection of the antibiotics and which were stored at $-70^{\circ} \mathrm{C}$ until the analyses were made. Only components corresponding to those of the antibiotic injected were detectable but as the analyses were made on unconcentrated urine some of the parent antibiotic may have been present at concentrations too low to be detectable.

Attempts were also made to identify the form in which the derivatives were excreted by measuring the antibacterial activity of the urine by means of a $2 \mathrm{hr}$ incubation test and expressing the relationship between this activity and that measured by the diffusion method as an activity index. Polymyxin B was used as the standard in this short incubation test and the activity detected by the method was expressed in terms of this standard, namely $\mu \mathrm{g}$ of polymyxin B per $\mathrm{ml}$. Indices below 1.0 therefore signify that the antibiotic in the urine has activity less than that of the parent antibiotic and that at least some is still present in the substituted form. The results of these estimations are given in Table 10, and they show that the indices are lowest after injection of the least acutely toxic derivative. In the in vitro tests described on pages 557-558 the activity of the least toxic of three samples, that of sulphomethyl-colistin, was shown to be one-twentieth of that of polymyxin B sulphate but in the urine the activity index is approximately 0.2 which shows that its activity is about one-fifth of that of the parent. This increase in activity indicates that a small but significant portion had changed to the parent form. 
TABLE 10

CONCENTRATION AND ACTIVITY INDEX OF THE ANTIBIOTIC IN SAMPLES OF HUMAN URINE PASSED AT 1 AND 4 HR AFTER THE ADMINISTRATION OF EQUIMOLAR DOSES OF DERIVATIVES OF THE POLYMYXINS OF DIFFERENT ACUTE INTRAVENOUS TOXICITIES

The concentrations were measured by the agar-diffusion method and the activity index was measured against Esch. coli in a short incubation method; the results are given as the ranges of the observed values from eight human volunteers. SM=sulpnomethyl. LD50s are intravenous

$\begin{array}{lcccc}\text { Antibiotic } & \begin{array}{c}\text { Time } \\ \text { (mg/kg) }\end{array} & \begin{array}{c}\text { after } \\ \text { injection } \\ (\mathrm{hr})\end{array} & \begin{array}{c}\text { Concen- } \\ \text { tration } \\ (\mu \mathrm{g} / \mathrm{ml} .)\end{array} & \begin{array}{c}\text { Activity } \\ \text { index }\end{array} \\ \text { SM-Polymyxin B } & 100 & 1 & 8-216 & 0 \cdot 36-0 \cdot 83 \\ & & 4 & 40-93 & 0 \cdot 25-0 \cdot 69 \\ \text { SM-Polymyxin E } & 150 & 1 & 50-224 & 0 \cdot 32-0 \cdot 37 \\ & & 4 & 49-108 & 0 \cdot 31-0 \cdot 52 \\ \text { SM-Colistin } & >550 & 1 & 80-231 & 0 \cdot 11-0 \cdot 17 \\ & & 4 & 99-161 & 0 \cdot 12-0 \cdot 25\end{array}$

Cerebrospinal fluid. No antibiotic could be detected $(<0.1 \mu \mathrm{g} / \mathrm{ml}$.) in the cerebrospinal fluid of dogs after the administration of polymyxin B sulphate, sulphomethylpolymyxin B (P62/87) or sulphomethyl-colistin, in spite of there being from 1 to $4 \mu \mathrm{g} / \mathrm{ml}$. present in the plasma. In these experiments the drugs were given to pairs of dogs in doses of $4 \mathrm{mg} / \mathrm{kg}$ at 9.30 a.m. and 2 p.m. and the cerebrospinal fluid was collected from the cisterna magna $2 \mathrm{hr}$ after the second dose.

Intrathecal injection. Experience with the parent antibiotic has shown that although the intrathecal injection of the polymyxins produces a pleocytosis in the cerebrospinal fluid the sulphates of polymyxin B and polymyxin E can be safely administered to infants by this route in doses of up to $4 \mathrm{mg}$ (Swift \& Bushby, 1951).

In dogs, weighing approximately 10 to $15 \mathrm{~kg}$, a single intracisternal injection of $1.2 \mathrm{mg}$ of polymyxin B sulphate per dog causes pleocytosis of about 4,000 cells $/ \mathrm{mm}^{3}$, and the injection of $4 \mathrm{mg}$ causes coma and death within 2 to 3 days. The sulphomethyl derivatives of polymyxin B are less toxic in this species; after the intracisternal injection into two dogs of $8 \mathrm{mg}$ of one of these derivatives, with an acute intravenous LD50 value of $150 \mathrm{mg} / \mathrm{kg}$, the number of cells in the cerebrospinal fluid rose to approximately 1,000 per $\mathrm{mm}^{3}$ and there was transitory weakness of the hind-limbs, from which the animals had recovered by the following day. After the injection of $16 \mathrm{mg}$ of this derivative into four dogs, however, the animals became comatose for 6 to $18 \mathrm{hr}$ after which it became apparent that they had developed a flaccid paralysis of the hind-limbs.

The derivative was also injected into one of the lateral cerebral ventricles of a dog, during pentobarbitone sodium anaesthesia; the dose was $1.2 \mathrm{mg}$ and the animal showed no adverse effects.

Bile. There appears to be little difference in the excretion of the different forms of the polymyxins in the bile. Two dogs anaesthetized with pentobarbitone sodium and with cannulated common bile ducts were given $3.75 \mathrm{mg} / \mathrm{kg}$ of polymyxin B sulphate by injection. Bile collected up to $30 \mathrm{~min}$ after the injection contained less than $1 \mu \mathrm{g} / \mathrm{ml}$. but concentrations ranging from 4 to $5 \mu \mathrm{g} / \mathrm{ml}$. were present from $45 \mathrm{~min}$ to $3 \mathrm{hr}$. These concentrations were measured by the diffusion method. 
In three dogs treated similarly but given a corresponding dose of sulphomethylpolymyxin B (P62/87), the corresponding concentrations in the bile were 2.5 to $4.0 \mu \mathrm{g} / \mathrm{ml}$.

\section{Electrophoretic analysis}

Electrophoretograms of polymyxin B sulphate, three samples of sulphomethylpolymyxin B of different LD50 values and a sample of sulphomethyl-colistin are

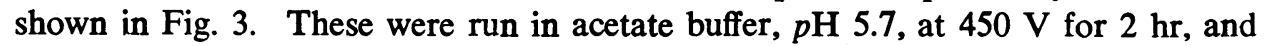

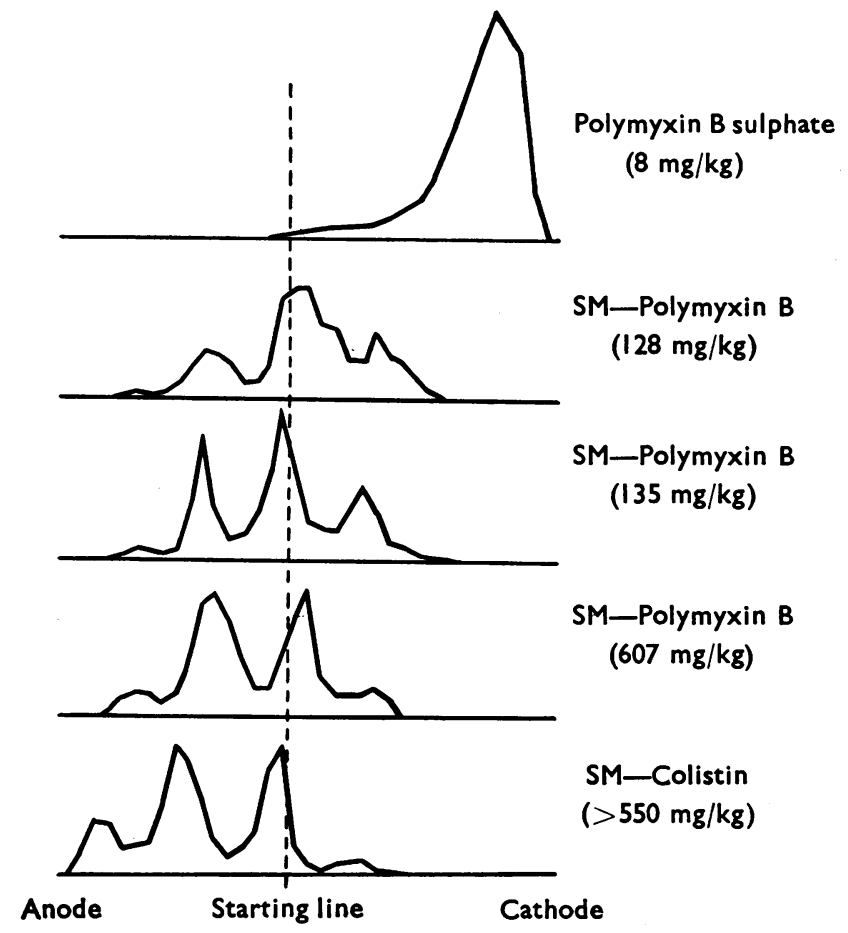

Fig. 3. Electrophoretograms of the active components in polymyxin B sulphate, in three samples of sulphomethyl-polymyxin B of different acute intravenous toxicities and in sulphomethylcolistin of low acute toxicity. Electrophoresis was at $p \mathrm{H} 5.7$ in $0.05 \mathrm{M}$-acetate buffer at $450 \mathrm{~V}$ for $2 \mathrm{hr}$. LD50 values are in parentheses.

the positions of the various components were detected microbiologically. Under these conditions polymyxin B sulphate behaves as a single component which migrates towards the cathode. The derivatives, however, are shown to be composite and to differ both qualitatively and quantitatively with the less toxic derivatives containing a higher proportion of the less basic components. The biological activities depicted in this figure are not a measure of the intrinsic activity of the respective components but they illustrate the amount of activity that is liberated when the components are in a glycine buffer at $p \mathrm{H} 2.0$. 
Treatment of the polymyxins with excess acetic anhydride produces stable inactive acetyl derivatives. Partial acetylation of polymyxin B, for example, gives a mixture of unchanged antibiotic and mono- to penta-acetyl-polymyxins. The derivatives can be separated electrophoretically and, except for the penta-acetyl-polymyxin B which does not react with ninhydrin, their positions can be detected by spraying with this reagent. Examination of the electrophoretogram for antibacterial activity shows that, apart from the parent antibiotic, only the mono-acetyl derivative is active. We have not isolated the mono-acetyl polymyxin B to measure its intrinsic activity but, judging by the intensity of the ninhydrin reaction and the size of the zone of inhibited growth of Bord. bronchiseptica, the derivative is much less active than the parent.

\section{DISCUSSION}

This study shows that treatment of polymyxin B and polymyxin E with formaldehyde and sodium bisulphite produces, under different conditions, a series of derivatives which differ quantitatively in acute intravenous toxicity and antibacterial activity.

Most of this study was made with polymyxin B and derivatives were prepared which have acute intravenous LD50 values for mice ranging from 54 to $607 \mathrm{mg} / \mathrm{kg}$; they are therefore one-seventh to one-eightieth as acutely toxic as the parent antibiotic. All these derivatives show less antibacterial activity than the parent antibiotic, the reduction being greatest with the least toxic samples but the exact amount depends on the method of assessment and the age of the solution. Methods in which a short incubation period is used show the greatest reduction, and in the quickest test that we were able to devise, namely measuring the bactericidal activity during 30 min exposure to freshly prepared solutions, the activity of the least toxic derivative (intravenous $L D 50,607 \mathrm{mg} / \mathrm{kg}$ ) was only $1.9 \%$ of that of the parent antibiotic and the activity of the most toxic derivative (intravenous LD50,54 mg/ $\mathrm{kg}$ ) was $12.4 \%$. When dilute solutions of these two derivatives were kept before assay for $3 \mathrm{hr}$ at $37^{\circ} \mathrm{C}$ the bactericidal activities increased to 4.8 and $19.2 \%$, respectively. By the more conventional methods of assay, which measure effects on the multiplication of the organisms during $18 \mathrm{hr}$ incubation, the reduction of activity was less, but, when a heavy inoculum and an incubation time of $3 \mathrm{hr}$ were used, the least toxic derivative still showed only $6 \%$ activity. Most workers who have compared the antibacterial activity of sodium sulphomethyl-colistin with that of colistin sulphate used a $24 \mathrm{hr}$ incubation test and found that under these conditions the derivatives showed about one-third of the activity of the parent antibiotic. It is clear from our results with the prolonged incubation test that activity depends on the particular sample of the derivative examined; the activities ranged from approximately 20 to $50 \%$ of that of the parent antibiotics.

The lability of $N$-sulphomethyl bonds is well recognized and the progressive increase in activity that occurs in solutions of the polymyxin derivatives is presumably due to unmasking the substituted amino groups. Electrophoresis of solutions of the derivatives show that, whilst unsubstituted polymyxin is absent, they are heterogenous; and as the components differ in charge, they presumably vary 
in the degree of substitution of the five free amino groups present in each of the parent antibiotics. The components also differ quantitatively in the various derivatives, the more acutely toxic ones being less highly substituted. Because of lability, it has not been possible to determine directly whether any of the components have intrinsic antibacterial activity, but partial acetylation of polymyxin B produces a mixture of stable mono- to penta-acetyl polymyxins which can be separated electrophoretically and their antibacterial activity determined. Only the mono-acetyl derivative is active and its activity is - much lower than that of unsubstituted polymyxin. Therefore, only the corresponding sulphomethyl derivative would be expected to have intrinsic activity; and as its activity would be much lower than that of the parent antibiotic, the activities shown in vitro and in vivo by the various derivatives must be almost, if not entirely, due to unmasking the substituted amino groups.

In contrast to the heterogenicity shown by electrophoresis, the results of elementary analysis, not described in this paper, indicate that each sample, irrespective of its acute intravenous toxicity, is fully substituted. In aqueous solution, each type of derivative must therefore form an equilibrium mixture of components of differing degrees of substitution.

Although full activity can be restored by keeping dilute solutions of the derivatives at $37^{\circ} \mathrm{C}$ for $24 \mathrm{hr}$, the relatively poor protection afforded by the derivatives to mice in the in vivo experiments shows that full restoration of activity does not occur in vivo. In the in vivo studies, the activity varied with the different derivatives, and the variations corresponded closely to those shown in the short incubation in vitro test. In the infection with Esch. coli the activities ranged from approximately one-half to one-thirtieth of that of the parent antibiotic but, in natural infections, these differences may not be so marked. This infection with Esch. coli is very acute and, in a comparison of drugs whose activation is necessary before they can exert their antibacterial effects, this infection probably exaggerates differences. Although this exaggeration would be less likely with the infection with Bord. pertussis, where death does not occur in untreated animals until 5 to 8 days after infection and where the activities of derivatives of low toxicity were only about onetenth of that shown by the parent antibiotic, it is still arguable that in natural infections of man these differences do not apply.

Probably the most useful way of forecasting the relative efficiencies of drugs that have similar modes of action is to determine their concentrations and duration in the blood after the administration of comparable doses. The usual biological methods are not applicable to these sulphomethyl-polymyxins because activation continues not only during the assay procedures but also during the interval between the collection of the samples of blood and the setting up of the assay. With antibiotics of this type the information required is not the actual concentration of antibiotic present but a measure of the antibacterial activity produced by the antibiotic in the circulating blood. We have attempted to obtain this information by determining the maximum dilution of the blood that is bactericidal and the results confirm those of the mouse experiments. Although the derivatives, irrespective of their intravenous toxicity, reach comparable concentrations in the blood, the 
bactericidal activities conferred on the blood by derivatives of low toxicity are substantially less than those obtained with the more toxic preparations.

Further confirmatory evidence of the higher stability in vivo of the low toxicity derivatives is the high concentration of antibiotic that is excreted in the urine after their administration. The parent antibiotics are very poorly excreted by the normal kidney, so high concentrations of antibiotic in the urine can be explained only by assuming that the antibiotic has passed through the kidney in the substituted form.

Clinical experience with the sulphomethyl derivatives of colistin has been reviewed (Hall, 1960 ; McMillan, Price, MacLaren \& Scott, 1962 ; Schwartz, Warren, Barkley \& Landis, 1959-60 ; Yow, Tan, Shane, Schonfeld \& Abu-Nasser, 1961 ; Petersdorf \& Plorde 1963) but without the writers realizing that the investigators have used two distinct types of derivatives. The derivative (Colomycin) used in Europe is of the low toxicity type with an acute intravenous LD50 value, according to the manufacturers, of $650 \mathrm{mg} / \mathrm{kg}$ for mice, and that used in America (Coly-Mycin ; WarnerChilcott) is of medium toxicity with an alleged intravenous LD50 value for mice of about $220 \mathrm{mg} / \mathrm{kg}$. This latter preparation would therefore be expected to show higher antibacterial activity than the one used in Europe, which had the least activity of any of the derivatives we have examined. In view of the quantitative differences in activity, these various preparations should be regarded as different polymyxin derivatives, and clinical results obtained with them should not be grouped together as though they were obtained with a single antibiotic. There is only one published reference (Clifford \& Stewart, 1961) to the use of sulphomethyl-polymyxin B and the particular sample used had an acute intravenous LD50 value for mice of $130 \mathrm{mg} / \mathrm{kg}$.

In their recent reappraisal of colistin, Petersdorf and Plorde (1963) concluded from the many published reports that although sulphomethyl-colistin is usually effective in controlling bacteriuria it is much less effective in the treatment of systemic infections. The success of colistin in sterilizing the urine is usually attributed to the high concentrations that are present in the urine, but polymyxin B sulphate itself is an effective drug for the treatment of urinary infections in spite of its low concentration in the urine; and more recent experience with sulphomethyl derivatives of colistin shows that, although the urine is usually sterilized during treatment, the organisms often reappear after the treatment is stopped. For complete eradication of a urinary infection, adequate concentrations of an active drug within the infected tissues of the urinary tract is probably more important than a high urinary concentration, so it is not surprising that relapses occur when the drug used is in a form that produces low activity in the blood. The relatively poor responses in systemic infections can also be attributed to circulation of the drug mainly in the inactive form and to loss of the antibiotic through the kidneys in an inactive form ; the results in systemic infections with this relatively nontoxic form of the sulphomethyl derivative (Colymycin) have been so disappointing that McMillan et al. (1962) recommend that the large daily dose of $720 \mathrm{mg}$ (9 megaunits) should be used ; Fekety, Norman \& Cluff (1962) reached similar conclusions.

Although the derivatives are more readily excreted in the urine than is the parent antibiotic, we have not been able to show that they are more readily excreted in the 
bile or that they pass into the cerebrospinal fluid of normal dogs. When injected into the theca, they are less irritant, and Clifford \& Stewart (1961) have shown that they can be safely injected intraventricularly into infants.

In the literature much value has been attached to the reduction in acute intravenous toxicity achieved by the sulphomethylation of the polymyxins, but with these antibiotics this toxicity is of no therapeutic importance because even in the unsubstituted form they have a satisfactory therapeutic index. The use of the polymyxins has, however, been much affected by the pain that develops at the site of intramuscular injection and by an undeserved reputation for nephrotoxicity. The painful reactions are undoubtedly avoided by using the sulphomethyl derivatives. The results of experiments in man, details of which are not reported in this paper, show that, provided the derivatives have intravenous LD50 values of $100 \mathrm{mg} / \mathrm{kg}$ or more, any reactions produced are insignificant compared with those produced by the parent antibiotics. The reputation of polymyxin $B$ and polymyxin $E$ for being nephrotoxic has arisen mainly because of the unfortunate use of a common generic name. The early and quickly discarded polymyxin $A$ and polymyxin $\mathrm{D}$ when used clinically did cause severe tubular degeneration and this effect has become undeservedly associated with the whole group ; the ready acceptance of polymyxin $\mathrm{E}$, when made available under the name of colistin, is an interesting example of the importance of a name. However, there is little doubt that, although both polymyxin B and polymyxin E (or colistin) can cause some tubular damage when given in excessively large doses, they can be safely used clinically. According to Hopper, Jawetz \& Hinman (1953) polymyxin B sulphate can be safely administered in doses of $2.2 \mathrm{mg} / \mathrm{kg} /$ day for 2 weeks to patients with normal renal function; similar conclusions regarding safety were reached by Yow \& Moyer (1953) and Swift \& Bushby (1953). According to Petersdorf \& Plorde (1963), although the earlier reports of clinical experiences with the derivatives of colistin indicated that in this form the antibiotic is not nephrotoxic in doses of $2 \mathrm{mg} / \mathrm{kg} / \mathrm{day}$, more recent reports show that signs of nephrotoxicity occur when doses are increased to 4 to $5 \mathrm{mg} / \mathrm{kg}$ in order to get a better therapeutic effect. Our experiments with rats indicate that the sulphomethyl derivatives of the polymyxins are a little less nephrotoxic than the unsubstituted drugs; we had to give the excessively large doses of $10 \mathrm{mg} / \mathrm{kg}$ of the parent antibiotics to produce proteinuria, and double this dose of the derivatives to produce the same effect. Transitory paraesthesia also occurs fairly frequently during administration of the polymyxins, and although its incidence appears to be lessened by using the derivatives, it still occurs.

The relatively poor therapeutic responses obtained with the two preparations of sulphomethyl-colistin that are at present available has prompted Petersdorf \& Plorde (1963) to suggest that in sensitivity tests the organisms should always be tested against the derivatives and not, as appears to be the common practice, against the parent antibiotic. While this recommendation ignores firstly, that the antibacterial activity of these derivatives depends on conversion to the parent antibiotic and secondly, that the conditions in the sensitivity tests do not necessarily represent those attained in vivo, it is nevertheless probably the best compromise, provided that 
the test is done on the derivative that is to be used clinically. This procedure will at least compensate to some extent for the difference in the stability of the different forms of the sulphomethyl derivatives.

The rapid bactericidal action of the polymyxins places them among the most powerful antibacterial drugs, and the introduction of the sulphomethyl derivatives has made parenteral therapy with these antibiotics tolerable for the patient, but, as abolition of painful reactions is achieved at the expense of therapeutic efficiency, detoxication should be minimal. The results of the in vitro and in vivo studies described in this paper show that the acute intravenous LD50 value is a useful index of therapeutic efficiency and that derivatives with LD50 values in the order of $100 \mathrm{mg} / \mathrm{kg}$ are the best compromise. The polymyxins are often used topically, but in concentrations which do not cause side-effects; in view of their need for activation the derivatives are contraindicated for this purpose. In severe systemic infections the most rapid effect will probably be obtained with the parent antibiotic, administered by slow intravenous infusion.

We wish to thank Mr P. A. Young and Miss B. R. Connell for help and advice on the statistical analysis, Dr V. Udall and Mr C. H. Burren for histological examination of the kidneys, Mr S. Bebbington for technical assistance and Miss M. Robinson for the assays of antibiotic in the urines.

\section{REFERENCES}

Bersin, T. (1957). Ion Exchangers in Organic and Biochemistry, p. 498. New York: Interscience Publications.

Bushiy, S. R. M. (1955). Sensitivity tests for the polymyxins. J. clin. Path., 8, 120-122.

Clifford, H. E. \& Stewart, G. T. (1961). Intraventricular administration of a new derivative of polymyxin B in meningitis due to Ps. pyocyanea. Lancet, ii, 177-180.

FeketY, F. R., Norman, P. S. \& Cluff, L. E. (1962). The treatment of Gram-negative bacillary infections with colistin. The toxicity and efficacy of large doses in forty-eight patients. Ann. intern. Med., 57, 214-229.

Hall, J. W. (1960). Colistin: Analysis of a new antibiotic in 44 cases of systemic Gram-negative bacterial infection. Amer. J. med. Sci., 240, 561-570.

Hopper, J, Jawetz, E. \& Hinman, F. (1953). Polymyxin B in chronic pyelonephritis: Observations on the safety of the drug and on its influence on the renal infection. Amer. J. med. Sci., 225, $402-409$.

Koyama, Y. (1957). Colimycin. G. ital. Chemioter., 4, 279-286.

LEPETrT, R. (1908-1910). Ethoxyphenylaminomethanesulphonate of sodium. Friedl., 9, 969-970.

LitchField, J. T. \& Wilcoxon, F. (1949). A simplified method of evaluating dose-effect experiments. J. Pharmacol. exp. Ther., 96, 99-113.

LogemanN, W. \& MioRI, G. P. (1955). Aldehyde bisulphite and formaldehyde sulphoxylate derivatives of amines and hydrazides for the improvement of activity, tolerance and solubility of medicinal compounds. Arzneimittel-Forsch., 5, 213-221.

McMillan, M., Price, T. M. L., Maclaren, D. M. \& Scott, G. W. (1962). Pseudomonas pyocyanea infection treated with colistin methane sulphonate. Lancet, ii, 737-739.

Petersdorf, R. G. \& Plorde, J. J. (1963). Colistin-a reappraisal. J. Amer. med. Ass., 183, 125-127.

Phillipe, J., Zuckerkande, F. \& Ores, B. (1959). Detoxication of neomycin. French Patent 795,984 .

SChif, H. (1866). Eine neue veihe organischer Di-amine. Liebigs Ann., Part 2, 140, 92-137.

SchWARTZ, B. S., WARREN, M. R., BARKLEY, F. A. \& LANDIs, L. (1959-1960). Microhiological and pharmacological studies of colistin sulfate and sodium colistinmethanesulfonate. Antibiotics Annual, (1960) pp. 41-60. New York: Antibiotica.

Stansly, P. G., ShePherd, R. G. \& White, H. J. (1947). Polymyxin: a new chemotherapeutic agent. Johns Hopk. Hosp. Bull., 81, 43-54.

Suzuki, T., Hayashi, K., Fujikawa, K. \& Tsukamoto, K. (1963). Identity of Polymyxin E1 to Colistin A and Polymyxin E 2 to Colistin B. Rep. Inst. Protein Res., Osaka University, Japan.

SWIFT, P. N. \& BushBY, S. R. M. (1951). Haemophilus influensae meningitis treated with polymyxin Lancet, ii, 183-190. 
SwIFT, P. N. \& Bushry, S. R. M. (1953). Clinical aspects of the toxicity of polymyxins A, B, and E. Lancet, i, 110-112.

Thompson, W. R. (1947). Use of moving averages interpolation to estimate median-effective dose. Bact. Rev., 11, 115-145.

TомoioKa, T., Soga, T. \& Umezuwa, S. (1960). N-methanesulphonate derivatives of gramicidin J. J. Antibiot. A (Tokyo), 13, 287-288.

WILKInSON, S. \& LowE, L. A. (1964). Structures of polymyxin B2 and E1. Nature (Lond.), 204, 145.

Yow, E. M. \& MoYeR, J. H. (1953). Toxicity of polymyxin B. II. Human studies with particular reference to evaluation of renal function. Arch. intern. Med., 92, 248-257.

Yow, E. M., TAN, E., Shane, L., Schonfeld, S. \& Abu-Nasser, H. (1961). Colistin (Coly-Mycin) in resistant bacterial infections. Arch. intern. Med., 108, 664-670. 